UDC 338.23

DOI https://doi.org/10.32849/2663-5313/2021.9.08

Denys Koshykov,

Doctor of Law, Senior Lecturer at the Department of Police Activity and Public Administration, Kharkiv National University of Internal Affairs, 27, Lev Landau avenue, Kharkiv, Ukraine, postal code 61080, Denyskoshykov@ukr.net

ORCID: orcid.org/0000-0002-0985-2897

Koshykov, Denys (2021). The concept and content of public policy on state economic security. Entrepreneurship, Economy and Law, 9, 52-57, doi: https://doi.org/10.32849/2663-5313/ 2021.9.08

\title{
THE CONCEPT AND CONTENT OF PUBLIC POLICY ON STATE ECONOMIC SECURITY
}

Abstract. Purpose. The aim of the article is to identify the concept and content of public policy on the economic security of the State. Results. Public policy on economic security is considered as the process of adopting legal regulations or managerial decisions in the field of economic security and the subsequent monitoring of their implementation; as a specific course (area) of economic security determined by the leadership of the State and implemented by authorized public administrators; as organizing and purposeful influence of authorized public administrators on public relations in the field of economic security by means of forms and methods defined by law. The objective of public policy on the economic security of the State is defined as creating conditions for the organization and development of public economic relations and ensuring social and economic rights and freedoms of citizens, as well as creating conditions for the further development and growth of the national economy and its competitiveness. It is proved that public policy on economic security of the State can include several components: 1) the legal and regulatory framework, consisting of laws and regulations on economic security and the regulatory mechanism for economic relations; 2) the institutional framework, composed of the competent public administration bodies and their officials authorised by law to ensure the economic security of the State; 3 ) the organizational framework, containing the principles, forms and methods of implementing public policy on economic security. Conclusions. It is established that, in accordance with the objectives of public policy on the economic security of the State, its sub-types are a regulatory and institutional policy on economic security, policy on economic rights of citizens, policy on the development of the national economy and economic relations, policy on digitalization of economic relations, economic and financial literacy of the population, law enforcement policy on economic security.

Key words: economic security, national security, public policy, administrative law framework, actors, administrative legislation, optimization.

\section{Introduction}

Economic security is an integral part of establishing an effective system of national security in Ukraine, since the deterioration of the economic situation may lead to a decline in industrial production, the bankruptcy of banks, the State budget's shortfall in funds for the development of strategic sectors of the economy, and social support for the population, which may have negative consequences in the form of unemployment, rising crime rates, threats of riots and the like.

Therefore, the State, acting through the competent bodies, should set a strategy for the development of all key sectors in order to streamline economic relations and ensure their stability and predictability, take adequate measures to improve the well-being of the population, taking into account objective economic laws. This course is generally referred to as public policy. Thus, it can be concluded that public policy on economic security requires a more detailed scientific study on the identified issues of social and world development.

In the current circumstances of state development resulting from the world economic crisis and constant changes in national legislation regulating economic relations in Ukraine, the content of public policy on the economic security of the State should be reconsidered.

2. The content of state policy on the economic security of the state

In a general social sense, policy is defined as the process in which a group of people, whose views or interests differ at the initial stage, makes a collective decision to bring the group together as a whole, which is introduced as a general course of action (Miller, 2000, p. 282). Policy is 
also considered as the sum of three interrelated aspects: 1) social life; 2) one of the activities of social actors; 3 ) a certain type of social relations (between individuals, small groups, etc.) (Vasilik \& Vershinin, 2001, p. 267).

From O.S. Vasiliev's perspective on policy as a manifestation of social activity, its separate elements are: 1) diversity of views. Policy assumes different views on certain situations, events, phenomena, etc. These views are most often associated with either the formulation of the ultimate goal or the consideration of different means of achieving the objective; 2) the decision-making mechanism. It is policy that determines how to reach agreement on collective decisions. Such ways mainly consist of three types of means: persuasion, negotiation, final decision; 3) decision-making procedure. The policy assumes that a decision made is considered as authoritative by a particular community of people. This decision becomes a policy as a course of action for this group of people (Vasyliev, 2014)

However, many academic writings consider policy from the perspective of state activities as art (science or practice) of the administration of the State or different political entities (Beliakov \& Matveicheva, 2009, p. 344).

This definition is quite consistent with the subject matter of the study, and therefore, a special type of policy - public policy on economic security - should be considered when analysing the role of the State in ensuring economic security. Theoretical works devoted to the organization and implementation of public policy defines it as:

- Activities of the State and its institutions aimed at ensuring public order, coordinating and subordinating various social interests, achieving social harmony and organizing the management of public development (Lohunova \& Shevchenko, 1999, p. 116).

- Conscious activities of authorities and institutions of state administration at various levels aimed at regulating social relations, ensuring their stability and development in accordance with a defined objective, a mode of public administration, which includes the formulation and implementation of political programmes for economic, social, cultural and political development (Rebkala \& Tertychky, 2000 p. 6 ; Kolodii, 2000, p. 503).

Based on general theoretical and specific definitions of public policy, one can conclude that to conclude that its typical features are:

- Public policy is related to certain acts of the State represented by its bodies and authorized officials. In addition, political parties may participate in the implementation of public policy as a voluntary association of citizens who are supporters of a national programme of social development aimed at promoting the formation and expression of citizens' political will. The participation of representatives of civil society in the implementation of public policy is also not excluded;

- Public policy may be both the activities and inactivity of authorized actors: public administration, political parties, etc.;

- The objective of public policy should be defined as regulation of some social relations in specific fields of state activities for their organization, protection and further development;

- A key aspect of public policy is the guarantee of rights and freedoms of natural and legal persons, facilitating their realization, protecting and restoring them in the event of violations;

- On the one hand, public policy should comply with the provisions of the legislation in force and, on the other hand, facilitate creation of legal provisions aimed at solving relevant social and economic problems, regulating and protecting social relations;

- The public policy measures are ensured by administrative authority of the certain actors, i.e., the application of administrative coercion measures;

- Public policy is accompanied by the adoption of state managerial decisions in the form of normative and individual managerial acts, as well as social and economic development programmes.

Therefore, based on a general theoretical analysis of the content of the concepts "politics" and "public policy", one can argue that public policy on the economic security of the State is a system of legislative, organizational and managerial measures enshrined in the legislation in force, which are implemented mainly by authorized public administrators with the participation of political parties, civil society institutions and representatives of business in order to organize and develop public economic relations and to ensure social and economic rights and freedoms of citizens, as well as to create conditions for the further development and growth of the national economy and the competitiveness of the State in the global economic environment.

The main features of public policy on economic security are:

1. Compliance with the provisions of the current legislation of Ukraine and consideration of the objective laws of the economy.

2 . Realization of citizens' social and economic rights and freedoms and establishment of the environment for the further development and growth of the national economy.

3. Implementation by specially authorised public administrators. Political parties, as well 
as representatives of civil society and the business environment, may be involved in these processes.

4. Implementation by means of special provisions of law, mainly of an administrative and legal nature, since they are adopted by authorized bodies of public administration for the implementation of legislative provisions. In this case, the administrative and legal regulatory mechanism ensures economic security of the State.

5. A set of forms and methods provided by law, among which the issuance of administrative acts, as well as methods of persuasion and coercion, takes pride of place.

6. Multi-level implementation (national, regional, local level).

7. Multi-pronged policies, as economic security of the State includes financial, macroeconomic, productive, energy, foreign economic and investment-innovation security.

8. Coordination and continuity in the establishment of a system of specially authorized bodies for its implementation, strategic and tactical decision-making, control over the obtained result and adjustments if necessary.

9. The criteria developed by the State, through its authorized bodies, to assess the effectiveness of economic security policies.

Moreover, the objective of public policy on the economic security of the State is the creation of environment for the organization and development of public economic relations and ensuring social and economic rights and freedoms of citizens, as well as the creation of the environment for the further development and growth of the national economy and its competitiveness. This objective is first and foremost achieved through the establishment of an appropriate legislative framework for economic security, as well as the establishment of an effective administrative and legal framework for the implementation of its provisions and regulations.

These features of public policy on economic security and its definition make it possible to argue that public policy on economic security can be understood as:

1) the process of adopting legal regulations or managerial decisions in the field of economic security and the subsequent monitoring of their implementation;

2) a specific course (area) of economic security determined by the leadership of the State and implemented by authorized public administrators;

3) an organizing and purposeful influence of authorized public administrators on public relations in the field of economic security by means of forms and methods defined by law.
Public policy on economic security of the State contains several elements:

1. The legal and regulatory framework that includes laws and regulations on economic security and the regulatory mechanism for economic relations. The regulatory framework also includes state and regional programmes for socio-economic development. The relevant laws and by-laws of Ukraine, as well as the international instruments ratified in accordance with established procedure, constitute the actual legal and regulatory framework for making public policy on economic security. The instruments under consideration can be grouped into those containing strategic and conceptual provisions for making public policy on economic security (laws, Strategies, Concepts), as well as those created to implement the provisions of the resolutions of the Cabinet of Ministers, State programmes, orders of central executive bodies, etc.

2. The institutional framework composed of competent public administration bodies and their officials authorised by law to ensure the economic security of the State in terms of issuing legal and individual regulations, applying state coercion. Moreover, the institutional component includes the Verkhovna Rada of Ukraine empowered to adopt Ukrainian laws in the relevant field, the President of Ukraine, who is the Chairman of the National Security and Defence Council of Ukraine, other state bodies entrusted with the protection of economic rights and freedoms of natural and legal persons, as well as the state.

These actors should be divided into two main groups: those responsible for formulating public policy on economic security and those responsible for implementing that policy. The first is the Verkhovna Rada of Ukraine and the President of Ukraine. The executive authorities and bodies of local self-government are mainly the implementors of public policy on economic security. In particular, the Cabinet of Ministers and other central executive authorities ensure the economic independence of Ukraine and the implementation of the State's domestic and foreign economic policy; take measures to ensure the economic rights and freedoms of individuals and citizens, the implementation of budgetary, financial, price, investment, tax, structural and sectoral policies, and draw up State-wide economic development programmes; ensure equal conditions for the development of all forms of ownership; legally regulate in fields of their responsibility (economy, finance, investment, energy, etc.). In addition, certain central executive bodies are responsible for monitoring the economic security of the State (Law of Ukraine 
on the Cabinet of Ministers of Ukraine, 2014; Law of Ukraine "On Central Executive Bodies", 2011).

3. The organizational framework which, in the author's opinion, contains the principles, forms and methods of implementing public policy on economic security of the State. The main forms of exercising the powers by the relevant actors are the issuance of legal regulations: laws and by-laws: decisions, orders, orders, etc. Moreover, it should be noted that the central executive authorities are responsible for monitoring the implementation of regulations on economic security. These powers are exercised in the form of checks, inspections and other administrative coercive measures, i.e., administrative liability.

Therefore, the analysis of these components of public policy on economic security allows arguing that a system of economic security consists of:

\begin{tabular}{|l|l|}
\hline Objective & $\begin{array}{l}\text { To organise and develop public eco- } \\
\text { nomic relations, ensure the realization } \\
\text { of citizens' social and economic rights } \\
\text { and freedoms, create conditions for } \\
\text { the further development and growth } \\
\text { of the national economy and ensure } \\
\text { the competitiveness of the State in } \\
\text { the global economic environment }\end{array}$ \\
\hline $\begin{array}{l}\text { Policy } \\
\text { Makers }\end{array}$ & $\begin{array}{l}\text { Supreme state authorities, executive } \\
\text { authorities and bodies of local self-gov- } \\
\text { ernment, institutions of civil society }\end{array}$ \\
\hline Object & $\begin{array}{l}\text { Social economic relations, economic } \\
\text { rights and freedoms }\end{array}$ \\
\hline $\begin{array}{l}\text { Instru- } \\
\text { ments }\end{array}$ & $\begin{array}{l}\text { Rulemaking, organizational actions, } \\
\text { methods of persuasion and coercion, } \\
\text { etc. }\end{array}$ \\
\hline
\end{tabular}

3. The task solved by the state policy on economic security

Given the above-mentioned concerning the constituent elements of the system of public policy on economic security, its key tasks at the present stage of the development of Ukraine are as follows:

1) To improve the provisions of current Ukrainian legislation in the economic sector by developing key laws and adopting strategic programmes in the field of economic security;

2) To establish an effective institutional system to implement the State's economic security strategy, to identify its key actors, their competences and the basis for cooperation and coordination;

3) To involve representatives of the business environment, specialized trade unions, representatives of small businesses and the scientific economic community in the development and implementation of economic security programmes and measures;
4) To increase the economy's resilience to the impact of external and internal challenges and threats, to improve the investment climate in the country, the budgetary planning processes and the socio-economic development of the regions, and the financial security system, as well as to optimise the regulatory and tax burden;

5) To develop an appropriate economic culture and financial literacy of the population;

6) To introduce modern information and communication technologies into the system of economic relations, enabling to improve the processes of economic transactions, to minimize the risks of parties and to facilitate financial and other services for the population;

7) To ensure the harmonious integration of Ukraine into the European and world economic security environment and the development of equitable and mutually advantageous economic relations with other States; as well as the State's participation in countering world economic threats and transnational economic crime;

8) To make legal and organizational grounds for citizens to exercise their economic rights and freedoms (rights to property, to entrepreneurial activities, etc.), to protect and restore them in the event of violations;

9) To form a fundamentally new system of control and law enforcement bodies entrusted with tasks in the field of economic security, and to exclude uncharacteristic powers from the subject matter competence of existing actors of law enforcement, in particular, with regard to interference in economic relations;

10) To adequately protect the information and communication infrastructure of the Ukrainian economy: payment systems, information banks, data registers, personal data of economic entities, etc.;

11) To lay the groundwork and take systematic measures against corruption, violations of anti-monopoly legislation, financial and economic crimes, especially those committed by organized criminal groups, and against the legalization of funds, illegally obtained.

Considering the list of tasks of public policy on economic security, sub-types can be distinguished as follows:

1. Regulatory and institutional policy on economic security. Its main objective is to establish an appropriate regulatory framework for economic relations and effective system of state bodies responsible for making public policy on economic security; for establishing an appropriate coordination mechanism for their activities and interaction.

2. Policy on economic rights of citizens and legal entities. The aim is to ensure 
and implement constitutional and regulatory guarantees for the exercise by citizens of their economic rights and increase the level of individual economic security and economic security of economic entities.

3. Policy on development of the national economy and economic relations. It involves targeted measures for the growth of sectors of the national economy, stability of the national currency, growth of GDP, industrial production, energy independence and investment attractiveness of the country.

4. Policy on digitalization of economic relations, economic and financial literacy of the population. It is aimed at consisting economic relations with the modern digital world characterized by introducing innovative developments and modern digital management systems into the economy, raising the awareness of the population about economic issues and their rights and obligations in the field of economy and economic security.

5. Law enforcement policy on economic security. It is implemented by specially authorized bodies of the State, that is, "law enforcement ones," and manifested by counteracting the most common economic offences (crimes, administrative misdemeanours), corruption, money laundering, financing of terrorism, cross-border economic crime.

\section{Conclusions}

By relying on the conducted research, it is expedient to make the following conclusions and generalizations:

1. Public policy on state economic security is the system of legislative, organizational and managerial measures enshrined in current legislation of Ukraine mainly implemented by authorized public administrators with the participation of political parties, civil society institutions and business representatives in order to organize and develop public economic relations and to ensure social and economic rights and freedoms of citizens, as well as to create conditions for the further development and growth of the national economy and the competitiveness of the State in the global economic environment (Koshykov, 2020).

2. Public policy on economic security can be understood as the process of adopting legal regulations or managerial decisions in the field of economic security and the subsequent monitoring of their implementation; as a specific course (area) of economic security determined by the leadership of the State and implemented by authorized public administrators; as organizing and purposeful influence of authorized public administrators on public relations in the field of economic security by means of forms and methods defined by law.

3. Public policy on economic security of the State has several components: the legal and regulatory framework, which includes laws and regulations on economic security, as well as the regulatory mechanism for economic relations; institutional composed of competent public administration bodies and their officials authorised by law to ensure the economic security of the State; the organizational framework which, in the author's opinion, contains principles, forms and methods of implementing public policy on economic security.

4. In accordance with the objectives of public policy on economic security of the State, its sub-types are a regulatory and institutional policy on economic security, policy on economic rights of citizens, policy on development of the national economy and economic relations, policy on digitalization of economic relations, economic and financial literacy of the population, law enforcement policy on economic security.

\section{References:}

Beliakov, A. \& Matveicheva, O. (Eds.). (2009). Bolshaia aktualnaia politicheskaia entciklopediia [Big topical political encyclopedia]. Moscow: Eksmo [in Russian].

Kolodii, A., Klymanska, L., Kosmyna, Ya. ta in. (Eds.). (2000). Politolohiia [Politology]. Kyiv: Elha-N. Nika-Tsentr [in Ukrainian].

Koshykov, D.O. (2020). Administratyvno-pravovi zasady realizatsii derzhavnoi polityky u sferi zabezpechennia ekonomichnoi bezpeky derzhavy [Administrative and legal bases of realization of the public policy in the field of maintenance of economic safety of the state]. Kharkiv : Panov [in Ukrainian].

Lohunova, M.M. \& Shevchenko, M.F. (1999). Kontseptualni zasady teorii polityky [Conceptual foundations of policy theory]. Kyiv: Vyd-vo UADU [in Ukrainian].

Miller, D. (2000). Entsyklopediia politychnoi dumky [Encyclopedia of political thought]. (N. Lysiuk, S. Aloshkinoi, I. Pidluskoi, Trans). Kyiv: Dukh i Litera [in Ukrainian].

Rebkala, V.A. \& Tertychky V.V. (Eds.). (2000). Derzhavna polityka: analiz ta mekhanizmy yii vprovadzhennia v Ukraini [Public policy: analysis and mechanisms of its implementation in Ukraine]. Kyiv: Vyd-vo UADU [in Ukrainian].

Vasilik, M.A. \& Vershinin, M.S. (2001). Politologiia [Political science]. Moskva: Gardariki [in Russian]. 
Vasyliev, O.S. Kontseptualizatsiia poniattia «derzhavna polityka»: suchasne rozuminnia [Conceptualization of the concept of "public policy": a modern understanding]. Derzhavne budivnytstvo State building, 1, Retrieved from http://nbuv.gov.ua/UJRN/DeBu_2014_1_7_[in Ukrainian].

Zakon Ukrainy Pro Kabinet Ministriv Ukrainy : pryiniatyi 27 liut. 2014 roku № 794-VII [Law of Ukraine On the Cabinet of Ministers of Ukraine from February 272014 № 794-VII]. (2014). rada.gov.ua. Retrieved from https://zakon.rada.gov.ua/laws/show/794-18_[in Ukrainian].

Zakon Ukrainy Pro tsentralni orhany vykonavchoi vlady : pryiniatyi 17 berez. 2011 № 3166-VI [Law of Ukraine On Central Executive Bodies from March 172011 № 3166-VI]. (2011). rada.gov.ua. Retrieved from https://zakon.rada.gov.ua/laws/show/3166-17_[in Ukrainian].

\section{Денис Кочиков,}

доктор юридичних наук, старший викладач кафедри поліцейської діяльності та публічного адміністрування, Харківський національний університет внутрішніх справ, проспект Льва Ландау, 27, Харків, Україна, індекс 61080,Denyskoshykov@ukr.net

ORCID: 0000-0002-0985-2897

\section{ПОНЯТТЯ ТА ЗМІСТ ДЕРЖАВНОЇ ПОЛІТИКИ У СФЕРІ ЗАБЕЗПЕЧЕННЯ ЕКОНОМІЧНОЇ БЕЗПЕКИ ДЕРЖАВИ}

Анотація. Метою статmi $є$ визначення поняття та змісту державної політики у сфері забезпечення економічної безпеки держави. Результати. Запропоновано державну політику у сфеpi економічної безпеки розуміти в таких аспектах: як процес ухвалення законодавчих актів або управлінських рішень у сфері економічної безпеки та подальший контроль за їх виконанням; як певний курс (напрям) у сфері економічної безпеки, який визначений керівництвом держави та реалізується уповноваженими суб'єктами публічної адміністрації; як організуючий цілеспрямований вплив уповноважених суб'єктів публічної адміністрації на суспільні відносини у сфері економічної безпеки за допомогою нормативно визначених форм і методів. Мету державної політики у сфері забезпечення економічної безпеки держави визначено як створення належних умов для впорядкування та розвитку суспільних економічних відносин, забезпечення реалізації соціальноекономічних прав і свобод громадян, а також створення умов для подальшого розвитку та зростання рівня національної економіки, забезпечення їі конкурентоспроможності. Доведено, що у структурі державної політики із забезпечення економічної безпеки держави можна виділити декілька складових елементів: 1) нормативно-правовий, до якого входять законодавчі та підзаконні акти з питань забезпечення економічної безпеки, а також регулювання економічних відносин; 2) інституційний, який становлять уповноважені органи публічної адміністрації та їх посадові особи, які мають нормативно закріплені повноваження щодо забезпечення економічної безпеки держави; 3) організаційний, який містить принципи, форми й методи реалізації державної політики у сфері забезпечення економічної безпеки. Висновки. Встановлено, що з огляду на завдання державної політики у сфері забезпечення економічної безпеки держави ії підвидами є нормативно-інституційна політика у сфері економічної безпеки, політика забезпечення економічних прав громадян, політика розвитку національної економіки та економічних відносин, політика цифровізації економічних відносин, політика забезпечення економічної та фінансової грамотності населення, правоохоронна політика у сфері економічної безпеки.

Ключові слова: економічна безпека, національна безпека, державна політика, адміністративноправові засади, суб'єкти, адміністративне законодавство, оптимізація.

The article was submitted 15.09.2021 The article was revised 06.10.2021 The article was accepted 25.10.2021 